\title{
The Procedural Rules of the Court of Arbitration for Sport
}

\author{
Mohamad Reza Davanloo ${ }^{1}$ \\ ${ }^{1}$ Payam Noor University Graduate Center (Campus), Tehran, Iran \\ Correspondence: Mohamad Reza Davanloo, Payam Noor University Graduate Center (Campus), Tehran, Iran.
}

Received: May 31, 2017

doi:10.5539/jpl.v10n4p156
Accepted: July 2, $2017 \quad$ Online Published: August 30, 2017

URL: https://doi.org/10.5539/jpl.v10n4p156

\begin{abstract}
The court of arbitration for sport is currently one of the main actors in the world of international sports. The court, established in 1984 by Juan Antonio Samaranch; the former president of the international Olympic committee, tries to settle the disputes arising in international sports in a specialized and efficient way through taking into account both rights and obligations of athletes and sports bodies. One of the most important success factors of the court is its procedural rules and regulations. These rules of the court are inserted in the code of arbitration for sport. The code created by the International Council of Arbitration for Sport tries to settle the sport related disputes in the best possible way to meet rights of the parties. In this procedure that is revised several times, core and fundamental legal principles such as process and procedural fairness are considered. Considering the significance of procedural rules in providing justice for parties in a dispute, this study is aimed in studying the different aspects of procedural rules of the court of arbitration for sports.
\end{abstract}

Keywords: procedural rules, proceedings, procedural fairness, procedural rules, the court of arbitration for sport

\section{Introduction}

Juan Antonio Samaranch (1981); as the Head of the International Olympic Committee, presented the idea of establishment of the Court of Arbitration for Sport (CAS) to settle the sport-related disputes in the sport family in specialized and fast way. Hence, the CAS was established in 1983 and began its work in Lausanne, Switzerland (Blackshaw, 2003). The court has been changed a lot during its lifetime more than 3 decades and the most important changes include independence of the court from National Olympic Committee and establishment of International Council of Arbitration for Sport (ICAS) (Naidoo \& Sarin, 2001). After that the Supreme Court of Switzerland confirmed the CAS as an independent court through two cases in 1992 and 2003 (Puljko, 2009), the main sport organizations of the world such as the International Olympic Committee and international federations gradually provided more supports for the court and the jurisdiction of the court were accepted by all people in practice. CAS that began its work on 1986 through handling a case registered 408 requests for arbitration by 2014. The number was increased to 500 cases in 2015 and this shows acceptance of global sport community for the court (Website Of CAS, 2015).

The Code of Arbitration for Sport approved in 1994 has been revised in several cases to the date. Since this date, the Procedural Rules inserted in CAS can handle cases of court for arbitration. The latest version of this code was entered into force in Jan 1 of 2016 and its text is available on internet base. CAS is currently formed of two departments of ordinary and appeal arbitration (Rigozzi, 2006). Moreover, since 1996, the International Council of Arbitration for Sport has also established a special unit for fast handling of the sport-related and disputes related to important competitions such as the Olympic Games and the football World Cup (Puljko, 2009). The specific and temporary branch that is responsible for solving disputes during $24 \mathrm{hrs}$ has been used iteratively to solve sport disputes during the Olympic Games and other important competitions like Football World Cup Games or Winter Olympic Games and competitions of commonwealth countries (Coccia, 2013; Website Of CAS, 2015). The branch includes also its specific Procedural Rules.

Procedural Rules for every court of justice can be one of the most important elements of the court for fair and legal handling of disputes and meeting rights of entities. It was mentioned that the court for arbitration has its special Procedural Rules that has predicted all affairs related to investigations from the time of demand of the applicants to continue the arbitration to the time of issuing the arbitration award. According to public interest of the sport organizations and institutes and athletes in CAS and importance of Procedural Rules in fair hearing, this study tends to investigate the Procedural Rules dominated on the types of hearing in the court. 
The Procedural Rules of the court are composed of two parts including Ordinary Arbitration procedure and Appeal Arbitration Procedure that are dominant on hearing method in the court with a few differences. According to article 27 of Code of Arbitration for Sport-related Disputes, These Procedural Rules apply whenever the parties have agreed to refer a sport-related dispute to the CAS. Such disputes may arise out of an arbitration clause inserted in a contract or regulations or of a later arbitration agreement (ordinary arbitration proceedings) or involve an appeal against a decision rendered by a federation, association or sports-related body where the statutes or regulations of such bodies, or a specific agreement provides for an appeal to the CAS (appeal arbitration proceedings). Such disputes may involve matters of principle relating to sport or matters of pecuniary or other interests brought into play in the practice or the development of sport and, generally speaking, any activity related or connected to sport. These Procedural Rules also apply where the CAS is called upon to give an advisory opinion (consultation proceedings) (Coccia, 2013). Hence, this study has firstly investigated the general provisions of all kinds of hearing of the court and then, it has studied the specific procedural rules of each type of hearing such as ordinary, appeal and temporary procedure.

\section{General Provisions}

As it was mentioned before, the procedural rules of the court are formed of two parts including ordinary procedural rules and appeal procedural rules that are dominant on the court with a few differences. Articles 27-37 and also articles 38-46 of the code are related to ordinary arbitration and articles 47-59 are related to appeal arbitration (Coccia, 2013). In this section, the common articles between two types of hearing are investigated and then, special rules of each of them are presented.

\section{Language of Arbitration}

According to article 29 of the code, The CAS working languages are French and English. In the absence of agreement between the parties, the President of the Panel or, if he has not yet been appointed, the President of the relevant Division, shall select one of these two languages as the language of the arbitration at the outset of the procedure, taking into account all pertinent circumstances. Then, the procedure is conducted exclusively in the language selected, unless the parties and the Panel agree otherwise (Code of Arbitration for Sport, 2016). According to paragraph 2 of article 29, the parties may choose another language provided that the Arbitration Panel agrees. The parties shall advise the CAS of such a choice. In the event of such a choice, the Panel may order that the parties bear all or part of the translation and interpreting costs. In some cases, the arbitration may go ahead using Spanish, German and Italian Languages with no problem (Coccia, 2013).

\section{Seat of Arbitration}

According to article 28 of this code, the seat of the CAS and of each Arbitration Panel ("Panel") is in Lausanne, Switzerland. However, should circumstances so warrant, and after consultation with all parties, the President of the Panel or, if he has not yet been appointed, the President of the relevant Division may decide to hold a hearing in another place and issues the appropriate directions related to such hearing. Determining seat for arbitration has several important legal effects:

- Whenever at least one party is not resident of Switzerland, the chapter 12 of Swiss Private International Law is dominant on arbitration.

- Domestic Swiss courts are qualified to have access to legal assistance doe arbitration (like summoning witnesses where they avoid to be present in arbitration or appointment or dismissal of arbitrators, if the parties have no agreement)

- In terms of reliability and sanction, awards are regarded based on The Convention on the Recognition and Enforcement of Foreign Arbitral Awards approval of 1958 by Switzerland (Blackshaw, 2006).

\section{List of Arbitrators}

One of the features of arbitration in the court is that choosing arbitrators is possible only from the list provided by The International Council of Arbitration for Sport. At the current age, about 300 arbitrators are present in this list from all continents of the world with agency of a wide range of legal, cultural and professional fields (Coccia, 2013). If one party appoints an arbitrator out of the list of arbitrators, the court's office, just similar to the time that no arbitrator is appointed and regardless of the appointed arbitrator, can appoint arbitrator on behalf of the beneficiary from a list of arbitrators of the court (Coccia, 2013). According to article 13 of CAS, The personalities designated by the ICAS, in conformity with Article S6, paragraph 3, appear on the CAS list for a renewable period of four years. The ICAS reviews the complete list every four years; the new list enters into force on 1 January of the following year. According to article 33 of the court, every arbitrator shall be and remain independent of the parties and shall immediately disclose any circumstances likely to affect his independence 
with respect to any of the parties. Every arbitrator shall appear on the list drawn up by the ICAS in accordance with the Statutes which are part of this Code, shall have a good command of the language of the arbitration, and shall have the availability required to expeditiously complete the arbitration (Code of Arbitration for Sport, 2016).

\section{Challenging Arbitrators}

According to article 34 of the code, an arbitrator may be challenged if the circumstances give rise to legitimate doubts over his independence. The challenge shall be brought within 7 days after the ground for the challenge has become known (Code of Arbitration for Sport, 2016) ${ }^{1}$. Independence of arbitrator shall be evaluated based on objective facts. According to part c of paragraph 1 of article 180 of Swiss Private International Law, An arbitrator may be challenged, if circumstances exist that give rise to justifiable doubts as to his independence. For example, economic dependence or continuous business relations can be examples of dependence of the $\operatorname{arbitrator}^{2}$ (Blackshaw, 2006). Such short time limitation is very important, since the Swiss Federal Court has announced several times that according to principle of goodwill and prohibition of abuse of the rights inserted in article 2 of the Civil Code of Swiss, challenging the arbitrator because of independence or impartiality is accepted just whenever it is created in time of hearing, since the person is not allowed to challenge the arbitrator after failure in gaining desired result; although the person was able to do it before that and during the hearing procedure (Coccia, 2013). Board of directors of the International Council of Arbitration for Sport makes a decision about challenging the arbitrator after gaining opinion of parties of lawsuit and other arbitrators (Code of Arbitration for Sport, 2016). Is the objection is confirmed by the International Council of Arbitration for Sport, the objected arbitrator is dismissed and new arbitrator is appointed based on common provisions; otherwise, the arbitrator remains on his position (Code of Arbitration for Sport, 2016). The decision of the council about challenging the arbitrator can't be protested independently and the benefited party can ask for an appeal after issuance of award of conviction in the Swiss Federal Court in accordance with paragraph 1 of article 90 of Swiss Private International Law (violence of law on dismissal of arbitrator) (Coccia, 2013).

\section{Provisional and Conservatory Measures}

The jury has no power before establishment and its establishment may last several months and this may lead to irreparable losses such as destruction of the existing property or evidence. Hence, similar to many business arbitration institutes with the power of issuing temporary awards, the CAS has allocated power to issue required orders for temporary measures till the date of formation of the jury to the President of Hearing (Mangan, 2009). Article 37 of CAS mentions: no party may apply for provisional or conservatory measures under these Procedural Rules before the request for arbitration or the statement of appeal, which implies the exhaustion of internal remedies, has been filed with the $\mathrm{CAS}^{3}$.

If an application for provisional measures is filed, the President of the relevant Division or the Panel invites the opponent to express his position within ten days or within a shorter time limit if circumstances so require. The President of the relevant Division or the Panel shall issue an order within a short time. In case of utmost urgency, the President of the relevant Division, prior to the transfer of the file to the Panel, or thereafter the President of the Panel may issue an order upon mere presentation of the application, provided that the opponent is heard subsequently (Code of Arbitration for Sport, 2016). The CAS has not presented limitative consideration of the cases of issuing a temporary order; although such request can be related to cases such as required measures to facilitate hearing like order to preserve important documents and prevent their destruction; the measures required to preserve existing condition or required measures to guarantee enforcement of award in future like confiscation of properties (Blackshaw, 2006). For example, in doping cases, temporary orders are issued to preserve the samples in a desired period (Code of Arbitration for Sport, 2016). After issuing a temporary order, the claimant shall register the arbitration application within 10 days (that is non-extendable deadline); otherwise, the

\footnotetext{
${ }^{1}$ Before this, decision making about challenging the arbitrator was among responsibilities of the arbitration panel; although the Supreme Court of Swiss announced it against public order and announced that the decision of panel about challenging the arbitrator is illogical, even if arbitration code has legitimated it.

${ }^{2}$ It should be mentioned that according to article 180 of Swiss Private International Law, An arbitrator may be challenged:

a. if he does not meet the qualifications agreed upon by the parties;

b. if a ground for challenge exists under the rules of arbitration

agreed upon by the parties;

c. if circumstances exist that give rise to justifiable doubts as to his independence.

${ }^{3}$ According to article 1 (183) of Swiss Private International Law, Unless the parties have otherwise agreed, the arbitral tribunal may, on motion of one party, order provisional or conservatory measures.
} 
temporary order would be null and void. Moreover, it is possible to consider conditions for the temporary award (Code of Arbitration for Sport, 2016). This measure is to prevent possible loss of the other party and is mainly in form of necessity of giving a financial guarantee to issue a temporary award.

\section{Ordinary Arbitration Procedure}

\subsection{Generalities}

According to article 20 of CAS, The Ordinary Arbitration Division constitutes Panels, whose task is to resolve disputes submitted to the ordinary procedure, and performs, through the intermediary of its President or his deputy, all other functions in relation to the smooth running of the proceedings conferred upon it by the Procedural Rules. After achievement of required conditions ${ }^{4}$, the arbitration demand would come to force and the arbitration panel composed of 1-3 arbitrators is established. If the number of arbitrators is not mentioned in the arbitration agreement, the president can determine number of arbitrators due to the conditions (depending on the cost and complexity of the dispute).

As arbitration is an agreement-based institute, the parties can make an agreement on appointing arbitrators from the list of arbitrators of the court similar to other cases; although in case of disagreement, the arbitrators are appointed based on the provisions of CAS (despite to appeal arbitration procedure, the parties in ordinary arbitration procedure have the freedom of choosing arbitrators). If it is decided to appoint one arbitrator based on the agreement of arbitration or decision of president, the parties shall agree on the appointment of an arbitrator within 15 days from the date of receipt of the request; otherwise, the president of the division can appoint the arbitrator (Code of Arbitration for Sport, 2016). However, if it is decided to appoint three arbitrators based on the agreement of arbitration panel or order of the president, in addition to submission of the request or after that, the claimant introduces the arbitrator in the deadline. Lack of introducing the arbitrator within the deadline by the claimant means withdrawal of arbitration. Moreover, the respondent shall introduce the appointed arbitrator within the deadline; otherwise, the arbitrator would be appointed by the president of the division. Two appointed arbitrators make an agreement within the deadline on the election of president of the arbitration panel and if no agreement is made, the president of division can elect the president by himself. Finally, the appointed arbitrators shall be confirmed in terms of required condition ${ }^{5}$ in article $33^{6}$ by the president of the division (Code of Arbitration for Sport, 2016). In accordance with article 44, the procedure before the Panel comprises written submissions and, if the Panel deems it appropriate, an oral hearing. Upon receipt of the file, the President of the Panel, if appropriate, shall issue directions in connection with the written submissions. As a general rule, there shall be one statement of claim, one response and, if the circumstances so require, one reply and one second response. The parties may, in the statement of claim and in the response, raise claims not contained in the request for arbitration and in the answer to the request. Thereafter, no party may raise any new claim without the consent of the other party. If the Claimant fails to submit its statement of claim in accordance with Article R44.1 of the Code, the request for arbitration shall be deemed withdrawn. If the Respondent fails to submit its response in accordance with Article R44.1 of the Code, the Panel may nevertheless proceed with the arbitration and deliver an award. If any of the parties is duly summoned yet fails to appear at the hearing, the Panel may nevertheless proceed with the hearing (Code of Arbitration for Sport, 2016).

\subsection{Confidentiality}

According to article 43, Proceedings under these Procedural Rules are confidential. The parties, the arbitrators and the CAS undertake not to disclose to any third party any facts or other information relating to the dispute or the proceedings. Awards shall not be made public unless the award itself so provides or all parties agree (Code of Arbitration for Sport, 2016).

\subsection{Law Applicable to the Merits}

According to article 45 of CAS, The Panel shall decide the dispute, according to the rules of law chosen by the

\footnotetext{
${ }^{4}$ According to article 38, the court takes measure to complete the defects of the request and allocates suitable deadline and if the defects are not met by the claimant in the deadline, the request can't come to force. Immediately after registering the request, the court refers it to ordinary or appeal arbitration proceedings due to the nature of dispute (5). Then, a copy of the request is sent to the respondent and a deadline is determined to reply. The reply can contain incompetency of the court, mutual claim and a summary of defenses of the respondent and can make parties to determine dominant rules on arbitration and appoint the arbitrators.

${ }^{5}$ Investigation in terms of impartiality and independence according to article 33 and being in list of arbitrators of CAS

${ }^{6}$ Article 33 of CAS: " Every arbitrator shall be and remain independent of the parties and shall immediately

disclose any circumstances likely to affect his independence with respect to any of the parties.Every arbitrator shall appear on the list drawn up by the ICAS in accordance with the Statutes which are part of this Code, shall have a good command of the language of the arbitration and shall have the availability required to expeditiously complete the arbitration. "
} 
parties or, in the absence of such a choice, according to Swiss law. Selecting a law applicable to merits by parties has been accepted in Lex Arbitr Law (chapter 12 of Swiss Private International Law) in international arbitrations. Article 187 of the said law has given no vast authority to parties to select law applicable to the merits and considered no certain condition for merits. Choosing the law applicable to the merits is not necessarily written and needs to stipulation. This issue can be perceived implicitly from the performance or behavior of merits; e.eg when they have considered specific rules or specific terminology of domestic law while drafting or enforcing the contract or when the parties have presented legal inferences based on a natural law in procedure of arbitration (Blackshaw, 2006). Despite to the vast authority of parties to select the law applicable, it should be mentioned that this rule has also some exceptions. According to some conditions the panel takes measure for hearing and issuing award regardless of selected law by parties and based on other law and this is the time that the selected law is against public order (Lois de Police) and binding rules (Lois D' Applicaion Immediate). If the parties have not specified the law applicable and have not also assigned it to the panel, article 45 of the Tribunal Arbitration Law appoints the Swiss Law as applicable law. In fact, the parties make the Swiss Law as applicable law through presenting the lawsuit to the court and without selection of applicable law (Blackshaw, 2006).

\subsection{Multiparty Arbitration}

Arbitration in the court, similar to many agreement of arbitration, is binding just for the parties and their deputy. However, the issue of effect of award of arbitrator on third party has been always existed. Clearly, arbitration awards can cause important consequences for entities not involved in hearing procedure (McLaren, 2001). Business Arbitration Rules are usually silent about entrance of a third party and it means that entrance of a third party is impossible unless with the consent of the parties. However, in Tribunal Law, third party can be involved under specific conditions (Mangan, 2009). The said law has explained rules on multilateral arbitration in article 41. According to this article, arbitration panel can be composed of more than two parties. The law has imagined 3 states in this assumption:

\subsection{Plurality of Claimants / Respondents}

If the request for arbitration names several Claimants and/or Respondents, the CAS shall proceed with the formation of the Panel in accordance with the number of arbitrators and the method of appointment agreed by all parties. In the absence of such an agreement, the President of the Division shall decide on the number of arbitrators in accordance with Article R40.1.

If a sole arbitrator is to be appointed, Article R40.2 shall apply. If three arbitrators are to be appointed and there are several Claimants, the Claimants shall jointly appoint an arbitrator. If three arbitrators are to be appointed and there are several Respondents, the Respondents shall jointly appoint an arbitrator. In the absence of such a joint appointment, the President of the Division shall proceed with the appointment in lieu of the Claimants/Respondents. If there are three or more parties with divergent interests, both arbitrators shall be appointed in accordance with the agreement between the parties. In the absence of such agreement, the arbitrators shall be appointed by the President of the Division in accordance with Article R40.2. In all cases, the arbitrators shall select the President of the Panel in accordance with Article R40.2 (Blackshaw, 2006).

\subsection{Joinder}

If a Respondent intends to cause a third party to participate in the arbitration, it shall mention it in its answer, together with the reasons therefor, and file an additional copy of its answer (Code of Arbitration for Sport, 2016). According to paragraph 3 of article 41, if a third party intends to participate as a party in the arbitration; it shall file with the CAS an application to this effect, together with the reasons therefor within the time limit set for the Respondent's answer to the request for arbitration. To the extent applicable, such application shall have the same contents as a request for arbitration.

The Court Office shall communicate a copy of this application to the parties and set a time limit for them to express their position on the participation of the third party and to file, to the extent applicable, an answer. After the deadline, the president of division makes decision regarding agreement of arbitration on joining third party. In case of acceptance of request for third party, the court forms the panel with agreement on all parties on number and way of appointment of arbitrators ${ }^{7}$.

\footnotetext{
${ }^{7}$ it should be noted that in addition to possibility of joining third party in arbitral cases, the temporary court has created a practical procedure since the time of Sidney's 2000 Olympic Games, in accordance to which it sends a declaration for the beneficiary third parties to announce the procedure to them (8).
} 


\subsection{Joint Provisions on Joinder and Intervention}

A third party may only participate in the arbitration if it is bound by the arbitration agreement or if itself and the other parties agree in writing. In this case, the respondent refers to this issue, along with other evidences, in the reply writing. The court sends a copy of the reply of the respondent for the claimant and gives good chance to announce the position. Clearly, the third party can participate in the arbitration whenever the person has a necessity for arbitration agreement or the parties have announced their consent in writing (Code of Arbitration for Sport, 2016).

\section{Appeal Arbitration Procedure}

\subsection{Generalities}

In accordance with article 47 of CAS, An appeal against the decision of a federation, association or sports-related body may be filed with the CAS insofar as the statutes or regulations of the said body so provide or as the parties have concluded a specific arbitration agreement and insofar as the Appellant has exhausted the legal remedies available to him prior to the appeal, in accordance with the statutes or regulations of the said sports-related body. Moreover, paragraph 2 of article 47 mentions that an appeal may be filed with the CAS against an award rendered by the CAS acting as a first instance tribunal if such appeal has been expressly provided by the rules applicable to the procedure of first instance (Code of Arbitration for Sport, 2016, Van Der Harst, 2016). Large volume of cases in field of appeal arbitration procedure is related to deprivation caused by doping. As the Football International Federation Association (FIFA) has accepted qualification of the court, the number of requests for appeal of the decisions related to transfer of football players is also being increased.

Although the process of appeal in the court is based on the principles of the decisions made by a sport federation, the jurisdiction of the court is not limited to legal territory of decision of federation and the protested subject. Paragraph 1 of article 57 mentions: the Panel shall have full power to review the facts and the law. It may issue a new decision which replaces the decision challenged or annul the decision and refer the case back to the previous instance. Upon transfer of the file, the President of the Panel shall issue directions in connection with the hearing for the examination of the parties, the witnesses and the experts, as well as for the oral arguments. He may also request communication of the file of the federation, association or sports-related body, whose decision is the subject of the appeal (Blackshaw, 2006). This issue as one of the most important specifications of appeal of the court is called as De Novo of appeal arbitration. In fact, court is not similar to an administrative court in position of revise of measures of an administrative institute with minimum standards. Administrative courts can just control the fairness or the award of objected party in terms of manner of decision making, effective evidence in decision, decision making ability and the jurisdiction of the decision making institute. On the contrary, the panel in appeal arbitration is responsible for entering into nature and evaluating the decision made and accuracy of observance of procedural rules (Coccia, 2013). The panel has the power to issue new award and replace it instead of the former award or cancel the former award and refer the case to issue new award to the initial hearing institute (Mangan, 2009). Hence, the parties can again have the chance to present their writing and other evidences and investigations of witnesses and experts.

Some entities in this field have criticized the specification of appeal arbitration procedure and have mentioned that de novo hearing needs consuming additional time and cost. In response to this criticism, it should be noted that without perfect hearing, including physical and natural investigation, arbitration of appeal branch can't be regarded as the awards issued from an arbitration institute and impose the enforcement consequences of New York arbitration convention in the enforcement of the awards. With the explanation that the revised disciplinary decisions by the court in appeal stage are generally made by dependent institutes such as the Disciplinary Commission of the International Olympic Committee that makes sometimes the decisions; to avoid creation of the doubt of dependence of the court in field of investigation of objected decisions, the appeal of the court shall be necessarily based on reinvestigations and perfectly (Rigozzi, 2006).

\subsection{Appeal Deadline}

The appeal procedure includes 2 stages. First, the claimant submits the appeal request to the court and then, he presents the evidences and documents in the appeal form. Usually, the appropriate rules of the federation shall be also observed, along with other formalities. The formalities may be different from rules of arbitration law; especially when time limitations are considered in the procedure. If no other deadline is considered for appeal in the provisions and bill of federation and relevant institute or association, the date of submission of the appeal is within 21 days after receiving decision of objected party. According to article 69 of CAS, submission of the appeal request is not accepted out of the deadline and in case of register of such request; the other party can ask the president of panel (ask president of the division in case of lack of establishment of the panel) for ending the 
hearing procedure anytime he wants even at the beginning of the procedure because of submission of the request after the deadline (Van Der Harst, 2016).

In the next stage, the appellant submits a summary of the legal events and procedure along with all evidences and documents, name of witness and a summary of provisions of witnesses and name of desired experts and their domain of specialization within 10 days from the expiration date of the deadline of presenting statement of appeal. After this deadline and lack of submission of the request, it is assumed that the appellant has canceled the appeal request (Code of Arbitration for Sport, 2016). The importance of the time limitation in submission of statement of appeal is usually neglected, especially the aspects of appeal that must include all realities and legal inferences and other evidences. Only in exceptional cases, when the realities and evidences are obtained consequently, the president $\mathrm{f}$ panel can accept the evidences after the deadline; unless the parties have achieved a specific agreement in this case. Particularly in doping cases, observance of this period to submit the appeal request is hard to do, since gaining specialized evidences and formation of the inspection case and doping research are time-consuming. Hence, because of difficulty of gaining specialized evidences to preset in the statement of appeal within the deadline, it is necessary in specific cases to accept the request out of the deadline. According to article 65 (Blackshaw, 2003), upon submission of the statement of appeal, the Appellant shall pay a minimum Court Office fee of Swiss francs 500, without which the CAS shall not proceed and the appeal shall be deemed withdrawn. The CAS shall in any event keep this fee (Van Der Harst, 2016).

After that, its turn to appoint the arbitrator from a selected list of Sport International Council. Afterwards, the jurisdiction of the CAS in handling the request is investigated. In appeal procedure, similar to ordinary procedure, the decision about jurisdiction is made by the panel (Code of Arbitration for Sport, 2016). The court office sends the statement of appeal to the respondent. The process of presenting the reply of the respondent has also two steps. In the first step, if the parties have not made an agreement on appointing the arbitrator, the respondent shall introduce the arbitrator within 10 days from the date of receiving the statement from list of the court arbitrators; otherwise, the president of division shall appoint the arbitrator (Code of Arbitration for Sport, 2016, Van Der Harst, 2016). According to article 55 of CAS, within twenty days from the receipt of the grounds for the appeal, the Respondent shall submit to the CAS an answer containing:

- $\quad$ a statement of defense;

- $\quad$ any defense of lack of jurisdiction;

- any counterclaim;

- Any exhibits or specification of other evidence upon which the Respondent intends to rely, including the names of the witnesses and experts whom he intends to call; the witness statements, if any, shall be filed together with the answer, unless the President of the Panel decides otherwise (Van Der Harst, 2016).

In case of objection to jurisdiction of the court, the panel or court office invites the objector to register written objection and after that, it makes decision in addition to a final award on its jurisdiction. In next measure, the president of division forms the panel and makes a decision about the request for suspension of the award or conditional measures if necessary (Code of Arbitration for Sport, 2016).

\subsection{Ad Hoc Division Procedure}

Ad hoc division arbitration of Olympic is investigated based on provisions of the Arbitration Rules for the Olympic Games. The panels or arbitrators investigate the disputes related to Olympic Games within 10 days from the opening ceremony of the Olympic Games in accordance with arbitration rules for Olympic Games ${ }^{8}$. According to arbitration rules of Olympic Games, every legal entity or institute tending to present a dispute in temporary branch of Court of Arbitration for Sport shall register a request in office of CAS. The request shall be in English or French. A standard application form is available in CAS office (Arbitration Rules for the Olympic Games, 2003). The temporary Branch announces the request notification and the date of hearing to the respondent. Moreover, in accordance with Arbitration Court Procedure, the third parties that may be affected by award of CAS shall also receive a notification (McLaren, 2001). Moreover, if National Olympic Committee is not one party of arbitration and has asked for no copy of the request, a copy would be also announced to them immediately after notification (Arbitration Rules for the Olympic Games, 2003). After registering the request in Court Office, it is turn to establish panel. The establishment manner of the panel and appointing arbitrators in temporary branch or other branches of CAS is different. The panel of CAS is responsible for appointing some

\footnotetext{
${ }^{8}$ Article 1 of Olympic Arbitration Law and article 61 of Charter of Olympic have recognized the jurisdiction of the court to settle the disputes of Olympic Games or related disputes in temporary Branch Court of Arbitration for Sport (11).
} 
arbitrators from the arbitrators in list of CAS to participate in the place of competitions (Arbitration Rules for the Olympic Games, 2003).

After receiving the arbitration request, the president of temporary branch established the panel through appointing several arbitrators from special list and also appoints the president of panel. The president of temporary branch can establish a panel with one arbitrator considering the conditions and its own discretion (Arbitration Rules for the Olympic Games, 2003). In this branch, appointing arbitrators is responsibility of the president of division and the parties play no role in determination of the arbitrator (s). However, it should be noted that the arbitrators in this branch shall also be absolutely independent from the parties and they are responsible for immediate disclosure of any factor endangering their independence (Arbitration Rules for the Olympic Games, 2003). The president of temporary branch usually avoids selecting arbitrators with common nationality with disputing parties. This issue is different from ordinary procedure and appeal or even with business arbitrations, since in these arbitrations, it happens abundantly that one or more arbitrators and even the president of panel have similar nationality to one of the disputing parties. This issue that has no legal stipulation is explainable according to the specific conditions of Olympic Games that are important from national perspective and from perspective of the competitors and public opinion (Coccia, 2013). However, if the evidences for any reason cause doubt in field of independence of one of arbitrators, he shall announce his own disqualification voluntarily, since he may be challenged or objected. The president of temporary branch is competent to hear the objections of parties. After giving the opportunity to the parties and the arbitrator and hearing their claims, he shall make appropriate decision in this field immediately. Objection to the arbitrator shall be presented immediately after specifying the evidences for objection (Arbitration Rules for the Olympic Games, 2003).

The panel sets the procedural rule in any manner that it recognizes; although the panel shall consider needs and specific conditions of each case, interests of parties and especially their right to hearing and necessity of the acceleration and efficiency as specifications of the branch. The panel shall summon all parties for a hearing session immediately after getting the arbitration application. In hearing session, the panel hears claims of parties and takes required measures about the evidences. The parties shall submit all evidences and documents in hearing session and introduce their witnesses. The witness shall be also heard immediately (Van Der Harst, 2016).

One of the clearest specifications of temporary branches of CAS is their speed in hearing. According to procedural rules of Olympic Games, the panel shall issue its award within 24hrs from the submission of the statement. In rare required cases, the president of branch can extent this deadline (Arbitration Rules for the Olympic Games, 2003, Raber, 1998). In cases of urgency, the panel if is established; otherwise the president of branch can make decision about the request for suspension of effects of objected decision or for any other preliminary award without hearing the claims of the respondent. The award is issued regarding some conditions such as probability of irreparable loss for the claimant, probability of winning of the claimant in nature of the case and value of interests of the claimant against the interests of the respondent. According to article 20 of CAS, all temporary measures would be null and void after issuance of award (Arbitration Rules for the Olympic Games, 2003). The decisions made by the temporary branch are binding and they can't be objected or appealed. However, to that level that appeal of awards of temporary branch is possible, limitation of the place of branch to Lausanne, Switzerland monopolizes the appeals to Swiss Federal Court (McLaren, 2001).

\section{Conclusion}

The Court of Arbitration for Sport has its specific procedural rules that are applied in all procedures and arbitral processes. The court is composed of 2 separated divisions to handle the disputes, including ordinary and appeal arbitration procedures. Each of the divisions has its specific procedural rules. Moreover, the court includes also a temporary branch that is specified to important sport competitions such as the Olympic and Football World Cup. This branch has also its specific rules (Arbitration Rules of the Olympic Games). According to CAS, the disputing parties can refer their dispute to this court after accepting arbitration of the court. Parties can appoint their desired arbitrator (s) from the list of experts and lawyers prepared by ICAS. During the ordinary arbitration procedure, those disputes are handles, in which the condition for referral of the dispute to court arbitration is inserted in the contract or in the arbitration agreement. The most important specification of this division is privacy and secrecy of hearing that is one of the clearest features of arbitration. Moreover, in this type of hearing, sometimes the participation and join of third party to the arbitration is possible.

When the claimant has objection to the issued award by the sport organizations or regulations of such organizations (whether directly or through referral to other sport rules), the case goes to the appeal procedure. 
This type of procedure with the highest volume of cases in the court has an important specification including de novo feature. It means that the appeal branch of CAS gives the chance to the parties to submit their evidences once again. In fact, such appealing is not only a formal and administrative investigation, but also the CAS again is involved in natural hearing and begins to investigate the case. As it was mentioned, the temporary branch of CAS established for fast settlement of the disputes caused by Olympic Games has its specific procedural rules. According to the rules, all cases referred during the competitions shall be investigated within $24 \mathrm{hrs}$. One of the most important specifications of the procedure of this branch can be lack of appointment of arbitrators by disputing parties and appointing them by the president of the division that is against the common procedure in arbitration rules.

It seems that in the procedural rules of the court, it has been tried to observe hearing formalities to provide conditions for a legal and fair hearing for the disputing parties. It could be mentioned that CAS has been successful to codify a set of comprehensive rules for arbitration for sport, which are required for a fair hearing, and this can be regarded as one of the success factors of CAS. The CAS has created an integrated procedural rule and has been successful to gain attention of athletes to its arbitration procedure. As its awards are regarded in line with national court's awards, it has all specifications and features of hearing procedure and formalities of a real court. Hence, it seems that the integrated and comprehensive procedural rules of this court can be an important instrument to create justice and fairness between claimants of the world of sport. Also, it has helped the court to achieve its ultimate goal that is being changed into the Supreme Court of World of Sport. However, it may face yet some defects and shortcomings in this way.

\section{References}

Arbitration Rules for the Olympic Games. (2003). Retrieved December 16, 2015, from http://www.tas-cas.org/en/arbitration/ad-hoc-division.html

Blackshaw, I. (2003). Court of Arbitration for Sport: An International Forum for Settling Disputes Effectively within the Family of Sport. Entertainment Law, 2(2), 61-83. https://doi.org/10.16997/eslj.139

Blackshaw, I. S., Siekmann, R. C., \& Soek, J. (2006). The Court of Arbitration for Sport: 1984-2004 (1st ed.). The Hague, TMC Asser Press. https://doi.org/10.1007/978-90-6704-591-9

Code of Arbitration for Sport. (2016). Retrieved October 10, 2016, from http://www.tas-cas.org/fileadmin/user_upload/Code_2016_final_en_.pdf

Coccia, M. (2013). International Sports Justice: The Court of Arbitration for Sport. International and Comparative Sports Justice. European Sports Law and Policy Bulletin, (1), 23-76.

Mangan, M. (2009). The Court of Arbitration for Sport: Current Practice, Emerging Trends and Future Hurdles. Arbitration International, 25(4), 591-602. https://doi.org/10.1093/arbitration/25.4.591

McLaren, R. H. (2001). Introducing the Court of Arbitration for Sport: The Ad Hoc Division at the Olympic Games. Marquette Sports Law Review, 12, 515-542.

Naidoo, U., \& Sarin, N. (2001). Dispute Resolution at Games Time. Fordham Intellectual Property, Media \& Entertainment Law Journal, 12, 489-507.

Puljko, V. (2009). Arbitration and Sport. Interdisciplinary Management Research, 5, 591-603.

Raber, N. K. (1998). Dispute Resolution in Olympic Sport: The court of arbitration for sport. The Seton Hall Journal of Sports and Entertainment Law, 8, 75-96.

Rigozzi, A. (2006). The Decisions Rendered by the CAS Ad Hoc Division at the Turin Winter Olympic Games 2006. Journal of International Arbitration, 23(5), 453-466.

Van Der Harst, M. (2016). Despina Mavromati and Matthieu Reeb: The Code of the Court of Arbitration for Sport: Commentary, Cases and Materials. The International Sports Law Journal, 1-2. https://doi.org/10.1007/s40318-016-0090-3

Website Of CAS. (2015). History of the CAS. Retrieved December 16, 2015, from http://www.tas-cas.org/en/general-information/history-of-the-cas.html

\section{Copyrights}

Copyright for this article is retained by the author(s), with first publication rights granted to the journal.

This is an open-access article distributed under the terms and conditions of the Creative Commons Attribution license (http://creativecommons.org/licenses/by/4.0/). 